\title{
Possible Relationship between Long-Term Adverse Health Effects of Gonad-Removing Surgical Sterilization and Luteinizing Hormone in Dogs
}

\author{
Michelle A. Kutzler D \\ Department of Animal and Rangeland Sciences, Oregon State University, 112 Withycombe Hall, Corvallis, \\ OR 97370, USA; michelle.kutzler@oregonstate.edu
}

Received: 10 March 2020; Accepted: 31 March 2020; Published: 1 April 2020

check for updates

Simple Summary: Spaying and neutering dogs is commonly used to prevent the birth of unwanted animals. However, spaying and neutering is associated with an increased risk of several long-term health problems including obesity, urinary incontinence, bladder stones, hypothyroidism, diabetes mellitus, hip dysplasia, cruciate ligament rupture, behavioral changes (including owner-directed aggression and fear), cognition problems, as well as several forms of cancer (including leukemia, prostate cancer, bone cancer, skin cancer, splenic cancer, and bladder cancer). An explanation of how spaying and neutering increases the risk of these long-term health problems is discussed in this review.

\begin{abstract}
Spaying and neutering dogs is commonly used to prevent the birth of unwanted animals and eliminate the risk of reproductive diseases. However, removal of the gonads prevents the feedback of estrogen and testosterone on the pituitary and hypothalamus. As a result, luteinizing hormone $(\mathrm{LH})$ is continuously elevated at supraphysiologic concentrations. Although the main role of LH is for reproductive function (e.g., ovulation), there are LH receptors present in several normal tissues including the thyroid and adrenal glands, gastrointestinal tract, cranial cruciate ligament and round ligament, and lymphocytes. In addition, there are LH receptors present in several neoplastic tissues (e.g., lymphoma, hemangiosarcoma, mastocytoma, transitional cell carcinoma, and osteosarcoma). The role of LH receptors in non-reproductive normal and neoplastic tissues is not known but may stimulate nitric oxide release and induce cell division. The precise etiology of the increased incidence of several non-reproductive long-term health complications following spaying and neutering is not known but may be related to LH receptor activation in these non-reproductive target tissues. How these effects may be mediated is described in this review.
\end{abstract}

Keywords: behavior; canine; luteinizing hormone; musculoskeletal; neoplasia; neuter; obesity; spay; urinary incontinence

\section{Introduction}

Throughout most of the developed world, surgical sterilization has become a common tool for combatting the overpopulation of unwanted dogs and eliminating the risk of reproductive diseases in pet dogs (e.g., mammary gland cancer and prostate hyperplasia/infection) [1-6]. In the United States, $64 \%$ of dogs have been surgically sterilized, and this is most commonly performed between 6 weeks and 12 months of age [7]. For this review, ovariectomy and ovariohysterectomy (spay) or castration (neuter) will be collectively referred to as gonadectomy, since each of these methods for surgical sterilization includes gonad removal (ovaries or testes).

In the normal adult mammal, the hypothalamus secretes gonadotropin-releasing hormone $(\mathrm{GnRH})$, which stimulates the anterior pituitary gland to release luteinizing hormone [8]. Luteinizing 
hormone (LH) stimulates the secretion of gonadal steroid hormones (testosterone in males and estrogen/progesterone in females). These gonadal steroid hormones then negatively feedback to the hypothalamus and anterior pituitary to decrease the secretion of $\mathrm{GnRH}$ and $\mathrm{LH}$, respectively. However, in the gonadectomized mammal, there is no negative feedback, which results in supraphysiologic circulating concentrations of $\mathrm{LH}$. In gonadectomized dogs, LH concentrations are more than thirty times the concentrations found in normal adult dogs [9]. Although the main role of LH is for reproductive functions (e.g., ovulation, corpus luteum formation), there are LH receptors present throughout the body, not just limited to the reproductive tract. The purpose of LH receptors in non-reproductive tissues is not known but may induce cell division and stimulate nitric oxide release [10]. With constant activation following gonad removal, these receptors can be upregulated (unpublished observations), further magnifying the effects of the supraphysiologic LH concentrations in non-reproductive tissues. The following review summarizes several non-reproductive long-term health complications resulting from spaying and neutering as well as discusses the possibility of how these effects are mediated by $\mathrm{LH}$ receptor activation in these non-reproductive target tissues.

\section{Non-Neoplastic Disorders}

Obesity is a serious medical problem defined as an excessive accumulation of fat beyond the physical and skeletal limits [11]. Gonad removal is the single largest risk factor for the development of obesity in dogs [12]. Up to $68 \%$ of spayed and neutered dogs are obese [13-18]. Gonadectomy induces obesity through two main mechanisms: increased appetite and decreased metabolic rate. Gonad removal stimulates food intake [19] and increases indiscriminate appetite [20]. In unaltered dogs, food intake suppresses the secretion of gastrointestinal hormones (cholecystokinin and glucagon), resulting in satiety (alleviation of hunger) [21]. However, within 1 week following de-sexing, food intake increases by $20 \%$ and then persists [22,23]. It is possible that stimulation of LH receptors (present in the gastrointestinal tract following gonadectomy) increases cholecystokinin and/or glucagon release. It is also possible that LH receptors in the hypothalamus are involved in the increase in appetite [24], as lesions within the ventromedial hypothalamus result in hyperphagia [25].

Urinary incontinence is an involuntary leakage of urine resulting from either a weakened or complete loss of urinary sphincter control. The association between urinary incontinence and gonad removal in female dogs was first described by Jo (1965) [26]. Urinary incontinence is a common long-term health complication of spaying female dogs, with a reported incidence ranging from $5 \%$ to $30 \%$ [27-30]. Early-age spaying (under 5 months of age) may further increase the risk of occurrence of urinary incontinence $[30,31]$ but the association between the age at spaying and the development of incontinence is weak. LH receptors are expressed in all regions of the canine lower urinary tract, from the body and neck of the bladder to the proximal and distal urethra [32,33]. Spayed female dogs with urinary incontinence have a significantly higher number of LH receptors in the lower urinary tract compared with unaltered females [34]. Urinary continence can be restored in spayed females using estrogens [29,35-38], GnRH agonists [39,40], or GnRH immunization [41,42]. These treatments all decrease circulating $\mathrm{LH}$ concentrations.

Urinary calculi are solid particles (concretions) in the urinary system, usually composed of mineral salts that can form in any part of the urinary tract [43]. After evaluating records from more than two million dogs, Banfield Pet Hospital found that all urinary calculi (urine crystals, kidney stones, and bladder stones) occurred at a rate three times higher in spayed and neutered dogs compared with unaltered dogs [44]. Under normal circumstances, there is a balance of urinary calculi promoters and inhibitors. However, this balance appears to be disrupted from the influence of an abundant LH environment.

Diabetes mellitus results from the impaired secretion of insulin with variable degrees of peripheral insulin resistance leading to hyperglycemia. In dogs, the incidence of diabetes mellitus is $0.4 \%-1.2 \%$ [45] and has been increasing over the past 30 years $[46,47]$. Gonad removal doubles the risk for developing diabetes mellitus in dogs [46]. Although gonadectomy increases the risk for obesity, the increased 
prevalence for diabetes mellitus in spayed and neutered dogs is unrelated to obesity $[48,49]$ and may be a direct effect of LH on the pancreas (e.g., chronic pancreatitis).

Hypothyroidism is a common endocrine disorder in which the thyroid gland does not produce sufficient quantities of thyroid hormone [50,51]. Gonad removal has a profound effect on thyroid function [52] and is the most significant cause for the development of hypothyroidism in dogs [53]. Thirty percent more spayed and neutered dogs develop hypothyroidism compared with unaltered dogs [54]. The concentrations of thyroxine in spayed and neutered dogs were significantly lower in both genders when compared with intact dogs [55]. Women who have undergone gonadectomy are also at an increased risk for developing hypothyroidism [56]. LH receptors are expressed in normal and adenomatous human thyroid glands [57]. Our laboratory has reported on the presence of LH receptors in the canine thyroid gland co-localized with thyroid stimulating hormone (TSH) receptors [58]. It is possible that continuous $\mathrm{LH}$ receptor activation is interfering with the mechanism of action of TSH in the thyroid, resulting in hypothyroidism.

Canine hip dysplasia is associated with the abnormal joint structure and laxity of the muscles, connective tissue, and ligaments that would normally support the hip [59-61]. As hip joint laxity increases, the articular surfaces between the acetabulum and the head of the femur lose contact with each other, resulting in subluxation. Over time, subluxation results in a significant change in the size and shape of both articular surfaces and varying severity of osteoarthritis. It is important to note that most dogs with hip dysplasia are born with normal hips but then develop hip dysplasia secondary to intrinsic and/or extrinsic factors. The incidence of hip dysplasia can be as high as $40 \%-83 \%$ in giant and large breed dogs $[59,62,63]$. However, the incidence of hip dysplasia varies considerably between different giant and large dog breeds. Independent of the occurrence of obesity, gonadectomy significantly increases the incidence of canine hip dysplasia [64]. Compared to unaltered dogs, gonadectomy increases this by 1.5 times [59] to 2 times [65] the occurrence in unaltered dogs. It is important to mention that the positive relationship between gonadectomy and the incidence of hip dysplasia is strongest in neutered male dogs as opposed to spayed female dogs. The mechanism for the increased incidence in certain breeds or sexes is not known but our laboratory has demonstrated the expression of LH receptors within the ligament of the head of the femur, the hyaline cartilage, and subchondral bone of the femur head [66]. It is possible that, in some dogs, an increase in LH receptor activation in the structural support tissues within the hip joint results in increased laxity, which is responsible for the higher occurrence of hip dysplasia in spayed and neutered dogs. However, our preliminary evidence has not shown a significant difference in LHR expression between sexes or reproductive statuses in these structural support tissues.

The cranial cruciate ligament serves to prevent cranial displacement of the tibia relative to the femur, to limit internal rotation of the tibia relative to the femur, and to prevent stifle hyperextension $[67,68]$. Cranial cruciate ligament rupture is another musculoskeletal disorder that initially involves the degeneration of the cranial cruciate ligament, which leads to a partial rupture and then progresses to a complete rupture following an unspectacular traumatic event [69,70]. Similar to hip dysplasia, most dogs with cranial cruciate ligament ruptures are born with normal stifle joints but then develop the tendency for cranial cruciate ligament rupture secondary to intrinsic and/or extrinsic factors. Gonad removal significantly increases the prevalence of cranial cruciate ligament rupture [71], doubling the occurrence reported for unaltered dogs [72], with an incidence as high as $5.1 \%$ and $7.7 \%$ in males and females, respectively [65]. Prepubertal spaying and neutering delays tibial growth plate closure, which extends the length of tibia and the steepness of the tibial plateau [73,74]. Increased steepness of the tibial plateau can increase the cranial tibial thrust, which is a risk for cranial cruciate ligament rupture $[75,76]$. Despite the skeletal deformations that occur with prepubertal gonadectomy (under 6 months), even dogs that are gonadectomized between 6 and 12 months have an increased risk for cranial cruciate ligament rupture [65]. There is some evidence that hormones (estrogen and relaxin) may play a role in altering cranial cruciate ligament laxity and modify risk factors in humans [77,78]. Our laboratory has demonstrated the expression of LH receptors within the cranial cruciate ligament [66]. It is possible 
that an increase in LH receptor activation in the cranial cruciate ligament results in increased laxity, which is responsible for the higher occurrence of ligament ruptures in spayed and neutered dogs.

The role of gonad removal on behavior is complex. Evidence for benefits as well as detriments following gonadectomy has been reported. Reproductive-related behaviors (such as urine marking in house, mounting, and roaming) are all reduced or eliminated following gonadectomy [79-81]. However, fear and aggression tend to be exacerbated [82]. Fear of storms, fear of gunfire, fear of noises, fear biting, timidity, separation anxiety, and submissive urination all increase significantly following spaying or neutering. Spayed females are also more reactive to the presence of unfamiliar humans and dogs [83]. Although some dogs may become less aggressive following gonadectomy [80], dominance aggression [84] and owner-directed aggression [20,85] occur with a significantly higher frequency in gonadectomized dogs compared with unaltered dogs. The hippocampus and hypothalamus both play important roles in controlling behaviors, especially those pertaining to fear and aggression. Luteinizing hormone receptors are abundant in the hippocampus and hypothalamus [86-88]. In addition, administration of supraphysiologic concentrations of LH to gonadectomized animals can induce aggression and other behavioral changes [89-91].

Cognitive dysfunction syndrome is a neurodegenerative disorder of senior dogs, which is characterized by both cognitive changes and neurophysiological pathologies [92,93]. Memory impairment, poor problem-solving skills, social disconnect, confusion, and day-night reversal may occur as the condition progresses. Gonad removal significantly increases the development and progression of cognitive dysfunction syndrome in dogs [94]. Increases in luteinizing hormone are associated with declines in cognitive performance [95]. In addition, elevated LH concentrations increase beta amyloid plaque formation and are implicated in the development of Alzheimer's syndrome in humans [96,97]. Therefore, it is possible that LH and its receptor are important in the development of cognitive dysfunction syndrome in spayed and neutered dogs.

\section{Neoplastic Disorders}

Unlike the condition in men, the aggressive nature of the canine prostate adenocarcinoma and the lack of a screening test make the identification of early-stage prostate cancer in dogs extremely problematic [98]. In dogs, gonadectomy is the largest risk factor for the development of prostate adenocarcinoma $[99,100]$. Luteinizing hormone receptors are abundant in the prostate gland and increase in expression following gonadectomy [101-103]. Prostate carcinomas in dogs are associated with a high rate of metastasis at presentation and poor prognosis even with aggressive local therapies [98]. Prostatectomy is associated with significant postoperative morbidity without significantly extending survival times [104,105].

Transitional cell carcinomas can arise from the bladder or urethra, including the prostatic urethra [106-110]. Even with surgical removal, radiation treatment and chemotherapy, the prognosis for dogs with transitional cell carcinomas is poor, with only $16 \%$ of treated dogs surviving for over one year [111]. Gonadectomized dogs have a significantly higher risk of developing a transitional cell carcinoma compared with unaltered dogs [111]. Luteinizing hormone receptors are widely distributed throughout the bladder and urethra and increase in expression following gonadectomy [32,33,112,113]. Our laboratory has also demonstrated the abundant expression of LH receptors in transitional cell carcinoma tissue.

Osteosarcoma is a highly metastatic cancer of bone tissue. Despite many advances over the past 20 years, survival times for dogs diagnosed with osteosarcoma have not changed, with the principal cause of mortality being the development of pulmonary metastases [114]. Osteosarcoma occurs with significantly higher frequency in spayed and neutered dogs [115]. The incidence of osteosarcoma in gonadectomized Rottweiler dogs is 1.3-2.0 times higher than in unaltered dogs [116]. However, there were no differences in the incidence of osteosarcoma between gonadectomized and unaltered German Shepherds. It is not known whether LH receptors exist in the bone or whether LH could be using an indirect mechanism to mediate the increased incidence of osteosarcoma. 
Hemangiosarcoma is a rapidly growing, highly invasive cancer arising from the lining of blood vessels and occurring almost exclusively in dogs. Primary tumors can arise in any vascular tissue, but the spleen and heart are the most common locations for hemangiosarcoma to develop. Even with surgical removal, the mean life expectancy is 86 days (range, 10-202 days) without adjunctive chemotherapy and 189 days (range, 118-241 days) with adjuvant chemotherapy [117]. Many studies have confirmed the presence of LH receptors in vascular endothelial and smooth muscle cells [118,119]. Spayed female dogs have two times the risk for developing splenic hemangiosarcoma and five times the risk for developing cardiac hemangiosarcoma compared with unaltered females [82,120]. Our laboratory has also demonstrated the expression of LH receptors in hemangiosarcomas, which may explain why this cancer is more common in spayed females [121].

Mastocytoma is the most common skin tumor in dogs [122]. Luteinizing hormone receptors are abundant in the skin $[32,123]$. Several studies have documented an increased risk for developing mastocytoma following spaying or neutering in dogs $[65,82,124]$. Our laboratory has shown that not only do mastocytomas express LH receptors, but that these tumors express three distinct patterns of LH receptor immunoexpression [125]. Moreover, mastocytomas from gonadectomized dogs had significantly higher more LHR-positive mast cells (84.2 $\pm 8.7 \%)$ overall. In addition, LHR-positive mast cells exhibiting the type 2 pattern $(66.6 \pm 15.3 \%)$ compared with mastocytomas from intact dogs $(64.3 \pm$ $4.2 \%$ and $49.2 \pm 8.4 \%$, respectively) [125]. The higher expression of LHR provides a mechanism that could be exploited in intervention strategies (e.g., using GnRH agonists) for mastocytoma recurrence in spayed and neutered dogs, leading to prolonged survival time.

Lymphoma is a cancer of lymphocytes and/or lymphoid tissues. Lymphoma is the most common cancer diagnosed in dogs, accounting for up to $24 \%$ of all canine cancers [126]. LH receptors are present in lymphocytes and lymphoid tissue (medulla of thymus) [127,128]. Our laboratory has demonstrated that the mean percentage of circulating LH receptor-positive T lymphocytes is significantly higher in gonadectomized dogs $(16.6 \%)$ than in sexually intact dogs $(10.5 \%)$; whereas the percentages of circulating LH receptor-positive B lymphocytes did not significantly differ by reproductive status [128]. Gonadectomy increases the incidence of lymphoma [82]. In Golden Retrievers, neutered males are three times more likely to develop lymphoma than unaltered males and approximately 1 in 10 neutered males will develop lymphoma [65]. Our laboratory has demonstrated that $12.4 \%$ of cells in canine neoplastic lymph nodes expressed LH receptors [128]. In addition, we showed that in vitro activation of LH receptors on T-lymphoma cells stimulates cell proliferation [129].

\section{Conclusions}

This review has focused the long-term adverse health effects of gonad-removing surgical sterilization in dogs in general. This review has not included differences in the occurrence of these adverse effects between age at spaying/neutering (early versus late), breed differences, or between sex differences. There is limited research addressing these points and a need for future research in these areas, especially as this research relates to differences in LHR expression. It is also important to note that, at present, there is no direct proof that there is a causative connection between elevated $\mathrm{LH}$ concentration/LHR expression and the long-term adverse health effects of spaying/neutering discussed in this review. More research on the causative connection between elevated LH concentration/LHR expression and the long-term adverse health effects of spaying/neutering is needed.

In addition, this review was focused on the long-term adverse health effects of gonad-removing surgical sterilization specifically in dogs. Although cats also suffer from long-term adverse effects of elevated LH concentrations following spaying/neutering (e.g., polyphagia, aggression and anxiety, diabetes), at the current time, the benefits of gonad removal (e.g., elimination of urine marking, recurrent/persistent estrus, mammary adenocarcinoma) outweigh these detriments.

Furthermore, this review has focused on the relationship between the long-term adverse health effects of gonad removal and elevated LH concentration/LHR expression. This review has not mentioned what, if any, effect that elevated follicle-stimulating hormone (FSH) concentrations have 
on the long-term adverse health effects of gonad removal. Although FSH concentrations are equally high in spayed/neutered dogs, FSH has extragonadal negative and positive feedback via pituitary inhibin and activin, respectively, whereas LH concentration has no extragonadal feedback. Additional research is needed on what role FSH concentrations/FSH receptors may play in the long-term adverse health effects of spaying/neutering.

Unrelated to any particular disease or major cause of death, years of gonad retention prolong longevity in a population of Rottweiler dogs [130]. Based upon the review of the literature, it becomes clear that canine gonads are not merely reproductive organs but are critical to endocrine, musculoskeletal, behavior, and anti-neoplastic health. Among the non-reproductive functions of gonads, suppression of LH secretion and resulting LH receptor overexpression appear necessary in maintaining homeostasis. Therefore, a surgical sterilization method that enables the dog to keep gonads intact while still preventing reproduction (e.g., ovary-sparing hysterectomy, vasectomy) may prolong their health, especially since the risk of fatal disease associated with retaining the gonads (mammary cancer, prostatic enlargement) is relatively low. In addition, research investigating the effect of LH/FSH down-regulation using a long-acting $\mathrm{GnRH}$ agonist (e.g., deslorelin) may provide a treatment option to mitigate or prevent the long-term adverse health effects of spaying/neutering.

Author Contributions: M.A.K. wrote the manuscript and approved the submitted version and agrees to be personally accountable to the accuracy or integrity of the work. All authors have read and agreed to the published version of the manuscript.

Funding: Research performed by the Kutzler Laboratory and presented within this review article was funded by the American Kennel Club Canine Health Foundation, Collie Health Foundation, and the Oregon State University Small Grants Program.

Acknowledgments: The Parsemus Foundation paid for the publication costs.

Conflicts of Interest: The author declares no conflict of interest.

\section{References}

1. Salmeri, K.R.; Olson, P.N.; Bloomberg, M.S. Elective gonadectomy in dogs: A review. J. Am. Vet. Med. Assoc. 1991, 198, 1183-1192.

2. Totton, S.C.; Wandeler, A.I.; Zinsstag, J.; Bauch, C.T.; Ribble, C.S.; Rosatte, R.C.; McEwen, S.A. Stray dog population demographics in Jodhpur, India following a population control/rabies vaccination program. Prev. Vet. Med. 2010, 97, 51-57. [CrossRef] [PubMed]

3. Voslarova, E.; Passantino, A. Stray dog and cat laws and enforcement in Czech Republic and in Italy. Annali dell'Istituto Superiore di Sanità 2012, 48, 97-104.

4. Domingues, L.R.; Cesar, J.A.; Fassa, A.G.; Domingues, M.R. Responsible pet animal guardianship in the urban area of the municipality of Pelotas in the state of Rio Grande do Sul, Brazil. Cien Saude Colet 2015, 20, 185-192. [CrossRef]

5. Downes, M.; Devitt, C.; Downes, M.T.; More, S.J. Neutering of cats and dogs in Ireland; pet owner self-reported perceptions of enabling and disabling factors in the decision to neuter. Peer] 2015, 3, 1196. [CrossRef]

6. Vanderstichel, R.; Forzán, M.; Perez, G.; Serpell, J.; Garde, E. Changes in blood testosterone concentrations after surgical and chemical sterilization of male free-roaming dogs in southern Chile. Theriogenology 2015, 83, 1021-1027. [CrossRef]

7. Trevejo, R.T.; Yang, M.; Lund, E.M. Epidemiology of surgical castration of dogs and cats in the United States. J. Am. Vet. Med. Assoc. 2011, 238, 898-904. [CrossRef]

8. Meethal, V.S.; Atwood, C.S. The role of hypothalamic-pituitary-gonadal hormones in the normal structure and functioning of the brain. Cell Mol. Life Sci. 2005, 62, 257-270.

9. Beijerink, N.; Buijtels, J.; Okkens, A.; Kooistra, H.; Dieleman, S. Basal and GnRH-induced secretion of FSH and LH in anestrous versus ovariectomized bitches. Theriogenology 2007, 67, 1039-1045. [CrossRef]

10. Greene, J.; Ginther, O. Circulating nitric oxide metabolites during luteolysis and the effect of luteinizing hormone on circulating nitric oxide metabolites in heifers. Theriogenology 2015, 83, 213-221. [CrossRef]

11. German, A.J. The Growing Problem of Obesity in Dogs and Cats. J. Nutr. 2006, 136, 1940S-1946S. [CrossRef] [PubMed] 
12. Martin, L.J.; Siliart, B.; Dumon, H.J.W.; Nguyen, P.G. Hormonal disturbances associated with obesity in dogs. J. Anim. Physiol. Anim. Nutr. 2006, 90, 355-360. [CrossRef] [PubMed]

13. Anderson, R.S. Obesity in dogs and cats. Vet. Ann. 1973, 183-186.

14. Mason, E. Obesity in pet dogs. Vet. Rec. 1970, 86, 612-616. [CrossRef]

15. David, G.; Rajendran, E.I. The after effects of spaying in bitches and cats. Cheiron 1980, 9, $193-195$.

16. Lefebvre, S.L.; Yang, M.; Wang, M.; Elliott, D.A.; Buff, P.R.; Lund, E.M. Effect of age at gonadectomy on the probability of dogs becoming overweight. J. Am. Vet. Med. Assoc. 2013, 243, 236-243. [CrossRef]

17. Lewis, L.D. Obesity in the dog. J. Am. Anim. Hosp. Assoc. 1978, 14, 402-409.

18. Norris, M.P.; Beaver, B.V. Application of behavior therapy techniques to the treatment of obesity in companion animals. J. Am. Vet. Med. Assoc. 1993, 202, 728-730.

19. Houpt, K.A. Feeding and Drinking Behavior Problems. Vet. Clin. North Am. Small Anim. Pr. 1991, 21, $281-298$. [CrossRef]

20. O'Farrell, V.; Peachey, E. Behavioural effects of ovariohysterectomy on hitches. J. Small Anim. Pr. 1990, 31, 595-598. [CrossRef]

21. Levine, A.S.; Sievert, C.E.; Morley, J.E.; Gosnell, B.A.; Silvis, S.E. Peptidergic regulation of feeding in the dog (Canis familiaris). Peptides 1984, 5, 675-679. [CrossRef]

22. A Houpt, K.; Coren, B.; Hintz, H.F.; E Hilderbrant, J. Effect of sex and reproductive status on sucrose preference, food intake, and body weight of dogs. J. Am. Vet. Med. Assoc. 1979, 174, 1083-1085. [PubMed]

23. Jeusette, I.; Detilleux, J.; Cuvelier, C.; Istasse, L.; Diez, M. Ad libitum feeding following ovariectomy in female Beagle dogs: Effect on maintenance energy requirement and on blood metabolites. J. Anim. Physiol. Anim. Nutr. 2004, 88, 117-121. [CrossRef] [PubMed]

24. Daniel, J.; Foradori, C.; Whitlock, B.; Sartin, J.; Whitlock, B.K. Hypothalamic Integration of Nutrient Status and Reproduction in the Sheep. Reprod. Domest. Anim. 2013, 48, 44-52. [CrossRef] [PubMed]

25. Rozkowska, E.; Fonberg, E. Salivary reactions after ventromedial hypothalamic lesions in dogs. Acta Neurobiol. Exp. 1973, 33, 553-562.

26. Joshua, J. The spaying of bitches. Vet. Rec. 1965, 77, 642-646.

27. Arnold, S. Urinary incontinence in castrated bitches. Part 1: Significance, clinical aspects and etiopathogenesis. Schweiz Arch Tierheilkd 1997, 139, 271-276.

28. Stöcklin-Gautschi, N.M.; Hässig, M.; Reichler, I.; Hubler, M.; Arnold, S. The relationship of urinary incontinence to early spaying in bitches. J. Reprod. Fertil. Suppl. 2001, 57, 233-236.

29. Angioletti, A.; De Francesco, I.; Vergottini, M.; Battocchio, M. Urinary incontinence after spaying in the bitch: Incidence and oestrogen-therapy. Vet. Res. Commun. 2004, 28, 153-155. [CrossRef]

30. Spain, C.V.; Scarlett, J.M.; Houpt, K.A. Long-term risks and benefits of early-age gonadectomy in dogs. J. Am. Vet. Med. Assoc. 2004, 224, 380-387. [CrossRef]

31. Thrusfield, M. Association between urinary incontinence and spaying in bitches. Vet. Rec. 1985, 116, 695 . [CrossRef] [PubMed]

32. Welle, M.; Reichler, I.M.; Barth, A.; Forster, U.; Sattler, U.; Arnold, S. Immunohistochemical localization and quantitative assessment of GnRH-, FSH-, and LH-receptor mRNA Expression in canine skin: A powerful tool to study the pathogenesis of side effects after spaying. Histochem. Cell Boil. 2006, 126, 527-535. [CrossRef] [PubMed]

33. Ponglowhapan, S.; Church, D.; Scaramuzzi, R.J.; Khalid, M. Luteinizing hormone and follicle-stimulating hormone receptors and their transcribed genes (mRNA) are present in the lower urinary tract of intact male and female dogs. Theriogenology 2007, 67, 353-366. [CrossRef] [PubMed]

34. Coit, V.; Dowell, F.; Evans, N. Neutering affects mRNA expression levels for the LH- and GnRH-receptors in the canine urinary bladder. Theriogenology 2009, 71, 239-247. [CrossRef]

35. Rosin, A.E.; Barsanti, J.A. Diagnosis of urinary incontinence in dogs: Role of the urethral pressure profile. J. Am. Vet. Med. Assoc. 1981, 178, 813-822.

36. Hill, K.; Jordan, D.; Ray, J.; Mays, A.A.; Griffin, K. Medical therapy for acquired urinary incontinence in dogs. Int. J. Pharm. Compd. 2012, 16, 369-375.

37. Veronesi, M.; Rota, A.; Battocchio, M.; Faustini, M.; Mollo, A. Spaying-related urinary incontinence and oestrogen therapy in the bitch. Acta Vet. Hung. 2009, 57, 171-182. [CrossRef]

38. Mandigers, P.J.J.; Nell, T. Treatment of bitches with acquired urinary incontinence with oestriol. Vet. Rec. 2001, 149, 764-767. [CrossRef] 
39. Reichler, I.; Hubler, M.; Jöchle, W.; Trigg, T.; Piché, C.; Arnold, S. The effect of GnRH analogs on urinary incontinence after ablation of the ovaries in dogs. Theriogenology 2003, 60, 1207-1216. [CrossRef]

40. Reichler, I.M.; Barth, A.; Piché, C.A.; Jochle, W.; Roos, M.; Hubler, M.; Arnold, S. Urodynamic parameters and plasma LH/FSH in spayed Beagle bitches before and 8 weeks after GnRH depot analogue treatment. Theriogenology 2006, 66, 2127-2136. [CrossRef]

41. Weston, M.K.A.; Donovan, C. Gonadotropin-Releasing Hormone Immunization to Treat Urethral Sphincter Mechanism Incompetence in a Bitch that Experienced an Adverse Reaction to Phenylpropanolamine. J. Vet. Sci. Med Diagn. 2013, 2, 3. [CrossRef]

42. Donovan, C.; Gordon, J.; A Kutzler, M. Gonadotropin-releasing hormone immunization for the treatment of urethral sphincter mechanism incompetence in ovariectomized bitches. Theriogenology 2014, 81, 196-202. [CrossRef] [PubMed]

43. Bartges, J.W.; Callens, A.J. Urolithiasis. Vet. Clin. North Am. Small Anim. Pr. 2015, 45, 747-768. [CrossRef] [PubMed]

44. Grauer, F.G. Prevalence of urinary calculi in dogs and cat. Todays Vet. Pract. 2015, 5, 13.

45. Bosch, M.N.; Pugliese, M.; Andrade, C.; Mahy, N.; Rodriguez, M.J. Amyloid- $\beta$ Immunotherapy Reduces Amyloid Plaques and Astroglial Reaction in Aged Domestic Dogs. Neurodegener. Dis. 2014, 15, $24-37$. [CrossRef]

46. Marmor, M.; Willeberg, P.; Glickman, L.T.; A Priester, W.; Cypess, R.H.; I Hurvitz, A. Epizootiologic patterns of diabetes mellitus in dogs. Am. J. Vet. Res. 1982, 43, 465-470.

47. Guptill, L.; Glickman, L.; Glickman, N. Time trends and risk factors for diabetes mellitus in dogs: Analysis of veterinary medical data base records (1970-1999). Vet. J. 2003, 165, 240-247. [CrossRef]

48. Rand, J.; Fleeman, L.M.; Farrow, H.A.; Appleton, D.J.; Lederer, R. Canine and Feline Diabetes Mellitus: Nature or Nurture? J. Nutr. 2004, 134, 2072S-2080S. [CrossRef]

49. Krook, L.; Larsson, S.; Rooney, J.R. The interrelationship of diabetes mellitus, obesity, and pyometra in the dog. Am. J. Vet. Res. 1960, 21, 120-127.

50. Mooney, C.T. Canine hypothyroidism: A review of aetiology and diagnosis. N. Z. Vet. J. 2011, 59, $105-114$. [CrossRef]

51. Scott-Moncrieff, J.C. Clinical Signs and Concurrent Diseases of Hypothyroidism in Dogs and Cats. Vet. Clin. N. Am. Small Anim. Pr. 2007, 37, 709-722. [CrossRef] [PubMed]

52. Dixon, R.; Mooney, C. Canine serum thyroglobulin autoantibodies in health, hypothyroidism and non-thyroidal illness. Res. Vet. Sci. 1999, 66, 243-246. [CrossRef] [PubMed]

53. Panciera, D.L. Hypothyroidism in dogs: 66 cases (1987-1992). J. Am. Vet. Med. Assoc. 1994, 204, 761-767.

54. Milne, K.L.; Hayes, H.M. Epidemiologic features of canine hypothyroidism. Cornell Vet. 1981, 71, 3-14.

55. Młodawska, K.A.; Max, A.; Bartyzel, B. Influence of gonadectomy on serum $\mathrm{ft} 4$ concentrations in male and female dogs. J. Pol. Agric. Univ. 2014, 17, 1-6.

56. De Leo, V.; D'Antona, D.; Lanzetta, D. Thyrotropin secretion before and after ovariectomy in premenopausal women. Gynecol. Endocrinol. 1993, 7, 279-283. [CrossRef] [PubMed]

57. Liu, J.; Chen, G.; Meng, X.; Liu, Z.-H.; Dong, S. Serum levels of sex hormones and expression of their receptors in thyroid tissue in female patients with various types of thyroid neoplasms. Pathol. Res. Pr. 2014, 210, 830-835. [CrossRef]

58. Zwida, K.; Kutzler, M. Luteinizing hormone receptor is immunoexpressed within the canine thyroid. Clin. Theriogenol. 2019, 11, 23-29.

59. Van Hagen, M.A.E.; Ducro, B.J.; Broek, J.V.D.; Knol, B.W. Incidence, risk factors, and heritability estimates of hind limb lameness caused by hip dysplasia in a birth cohort of boxers. Am. J. Vet. Res. 2005, 66, 307-312. [CrossRef]

60. Dassler, C.L. Canine hip dysplasia: Diagnosis and nonsurgical treatment. In Textbook of Small Animal Surgery, 3rd ed.; Slatter, D., Ed.; Saunders: Philadelphia, PA, USA, 2003; pp. 2019-2020.

61. Demko, J.; McLaughlin, R. Developmental Orthopedic Disease. Vet. Clin. North Am. Small Anim. Pr. 2005, 35, 1111-1135. [CrossRef]

62. Martin, S.W.; Kirby, K.; Pennock, P.W. Canine Hip Dysplasia: Breed Effects. Can. Vet. J. 1980, 21, $293-296$.

63. Priester, W.A.; Mulvihill, J.J. Canine hip dysplasia: Relative risk by sex, size, and breed, and comparative aspects. J. Am. Vet. Med. Assoc. 1972, 160, 735-739. 
64. Witsberger, T.H.; Villamil, J.A.; Schultz, L.G.; Hahn, A.W.; Cook, J.L. Prevalence of and risk factors for hip dysplasia and cranial cruciate ligament deficiency in dogs. J. Am. Vet. Med. Assoc. 2008, 232, 1818-1824. [CrossRef]

65. De La Riva, G.T.; Hart, B.L.; Farver, T.B.; Oberbauer, A.M.; Messam, L.; Willits, N.; Hart, L.A. Neutering Dogs: Effects on Joint Disorders and Cancers in Golden Retrievers. PLoS ONE 2013, 8, e55937. [CrossRef]

66. Kiefel, C.; Kutzler, M.A. Luteinizing hormone receptor expression in canine anterior cruciate and femoral head ligaments. In Proceedings of the International Symposium on Canine and Feline Reproduction, Paris, France, 22-25 June 2016.

67. Asher, L.; Grainger, K.; Grierson, J. An investigation into risk factors for bilateral canine cruciate ligament rupture. Vet. Comp. Orthop. Traumatol. 2011, 24, 192-196. [CrossRef]

68. De Rooster, H.; De Bruin, T.; Van Bree, H. Morphology and Function of the Cruciate Ligaments. In Advances in the Canine Cranial Cruciate Ligament; Wiley: Hoboken, NJ, USA, 2013; pp. 1-12.

69. Knebel, J.; Meyer-Lindenberg, A. Aetiology, pathogenesis, diagnostics and therapy of cranial cruciate ligament rupture in dogs. Tierärztliche Praxis Ausgabe K Kleintiere Heimtiere 2014, 42, 36-47.

70. Vasseur, P.B.; Pool, R.R.; Arnoczky, S.P.; E Lau, R. Correlative biomechanical and histologic study of the cranial cruciate ligament in dogs. Am. J. Vet. Res. 1985, 46, 1842-1954.

71. Duval, J.M.; Budsberg, S.C.; Flo, G.L.; Sammarco, J.L. Breed, sex, and body weight as risk factors for rupture of the cranial cruciate ligament in young dogs. J. Am. Vet. Med. Assoc. 1999, 215, 811-814.

72. Whitehair, J.G.; Vasseur, P.B.; Willits, N.H. Epidemiology of cranial cruciate ligament rupture in dogs. J. Am. Vet. Med. Assoc. 1993, 203, 1016-1019.

73. Osmond, C.S.; Marcellin-Little, D.; Harrysson, O.L.A.; Kidd, L.B. Morphometric assessment of the proximal portion of the tibia in dogs with and without cranial cruciate ligament rupture. Vet. Radiol. Ultrasound 2006, 47, 136-141. [CrossRef]

74. Griffon, D.J. A Review of the Pathogenesis of Canine Cranial Cruciate Ligament Disease as a Basis for Future Preventive Strategies. Vet. Surg. 2010, 39, 399-409. [CrossRef]

75. Slocum, B.; Devine, T. Cranial tibial thrust: A primary force in the canine stifle. J. Am. Vet. Med. Assoc. 1983, 183, 456-459.

76. Morris, E.; Lipowitz, A.J. Comparison of tibial plateau angles in dogs with and without cranial cruciate ligament injuries. J. Am. Vet. Med. Assoc. 2001, 218, 363-366. [CrossRef] [PubMed]

77. Prodromos, C.C.; Han, Y.; Rogowski, J.; Joyce, B.; Shi, K. A Meta-analysis of the Incidence of Anterior Cruciate Ligament Tears as a Function of Gender, Sport, and a Knee Injury-Reduction Regimen. Arthrosc. J. Arthrosc. Relat. Surg. 2007, 23, 1320-1325. [CrossRef] [PubMed]

78. Dragoo, J.; Castillo, T.N.; Braun, H.J.; Ridley, B.A.; Kennedy, A.C.; Golish, S.R. Prospective Correlation Between Serum Relaxin Concentration and Anterior Cruciate Ligament Tears Among Elite Collegiate Female Athletes. Am. J. Sports Med. 2011, 39, 2175-2180. [CrossRef]

79. Hopkins, S.G.; A Schubert, T.; Hart, B.L. Castration of adult male dogs: Effects on roaming, aggression, urine marking, and mounting. J. Am. Vet. Med. Assoc. 1976, 168, 1108-1110.

80. Neilson, J.C.; A Eckstein, R.; Hart, B.L. Effects of castration on problem behaviors in male dogs with reference to age and duration of behavior. J. Am. Vet. Med. Assoc. 1997, 211, 180-182.

81. Maarchalkerweerd, R.J.; Endenburg, N.; Kirpensteijn, J.; Knol, B.W. Influence of orchiectomy on canine behavior. Vet. Rec. 1997, 140, 617-619. [CrossRef] [PubMed]

82. Zink, M.C.; Farhoody, P.; Elser, S.E.; Ruffini, L.D.; Gibbons, T.A.; Rieger, R.H. Evaluation of the risk and age of onset of cancer and behavioral disorders in gonadectomized Vizslas. J. Am. Vet. Med. Assoc. 2014, 244, 309-319. [CrossRef] [PubMed]

83. Kim, H.H.; Yeon, S.C.; Houpt, K.A.; Lee, H.C.; Chang, H.H.; Lee, H.J. Effects of ovariohysterectomy on reactivity in German Shepherd dogs. Vet. J. 2006, 172, 154-159. [CrossRef] [PubMed]

84. Borchelt, P.L. Aggressive behavior of dogs kept as companion animals: Classification and influence of sex, reproductive status and breed. Appl. Anim. Ethol. 1983, 10, 45-61. [CrossRef]

85. Reisner, I.R.; Houpt, K.A.; Shofer, F.S. National survey of owner-directed aggression in English Springer Spaniels. J. Am. Vet. Med. Assoc. 2005, 227, 1594-1603. [CrossRef] [PubMed]

86. Lei, Z.M.; Rao, C.V.; Kornyei, J.L.; Licht, P.; Hiatt, E.S. Novel expression of human chorionic gonadotropin/luteinizing hormone receptor gene in brain. Endocrinology 1993, 132, 2262-2270. [CrossRef] 
87. Croxatto, H.; Arrau, J.; Croxatto, H. Luteinizing Hormone-like Activity in Human Median Eminence Extracts. Nature 1964, 204, 584-585. [CrossRef]

88. Bagshawe, K.D.; Orr, A.H.; Rushworth, A.G.J. Relationship between Concentrations of Human Chorionic Gonadotrophin in Plasma and Cerebrospinal Fluid. Nature 1968, 217, 950-951. [CrossRef]

89. Emanuele, N.V.; Tentler, J.; Scanlon, S.; Reda, D.; Kirsteins, L. Intracerebroventricular luteinizing-hormone (LH) depresses feeding in male-rats. Neuro Endocrinol. Lett. 1991, 13, 413-418.

90. Kawakami, M.; Sawyer, C.H. Induction of behavioral and electroencephalographic changes in the rabbit by hormone administration or brain stimulation 1. Endocrinology 1959, 65, 631-643. [CrossRef]

91. Telegdy, G.; Rozsahegyi, G. Effect of gonadotropins on extinction of an avoidance conditioned reflex and exploratory behaviors in the rat. Acta Physiol. Acad. Sci. Hung. 1971, 40, 209-214.

92. Oates, S.M. Uncloaking cognitive decline: The emergence of canine cognitive dysfunction in veterinary medicine and its implications for understanding Alzheimer's disease. Vet. Herit. Bull. Am. Vet. Hist. Soc. 2014, 37, 47-51.

93. Schütt, T.; Toft, N.; Berendt, M. Cognitive Function, Progression of Age-related Behavioral Changes, Biomarkers, and Survival in Dogs More Than 8 Years Old. J. Vet. Intern. Med. 2015, 29, 1569-1577. [CrossRef]

94. Hart, B.L. Effect of gonadectomy on subsequent development of age-related cognitive impairment in dogs. J. Am. Vet. Med. Assoc. 2001, 219, 51-56. [CrossRef] [PubMed]

95. Casadesus, G.; Milliken, E.L.; Webber, K.M.; Bowen, R.L.; Lei, Z.; Rao, C.V.; Perry, G.; A Keri, R.; Smith, M.A. Increases in luteinizing hormone are associated with declines in cognitive performance. Mol. Cell. Endocrinol. 2007, 269, 107-111. [CrossRef] [PubMed]

96. Verdile, G.; for the AIBL Research Group; Laws, S.M.; Henley, D.; Ames, D.; Bush, A.I.; Ellis, K.; Faux, N.G.; Gupta, V.B.; Li, Q.-X.; et al. Associations between gonadotropins, testosterone and $\beta$ amyloid in men at risk of Alzheimer's disease. Mol. Psychiatry 2012, 19, 69-75. [CrossRef] [PubMed]

97. Butchart, J.; Birch, B.; Bassily, R.; Wolfe, L.; Holmes, C. Male Sex Hormones and Systemic Inflammation in Alzheimer Disease. Alzheimer Dis. Assoc. Disord. 2013, 27, 153-156. [CrossRef]

98. Leroy, B.E.; Northrup, N. Prostate cancer in dogs: Comparative and clinical aspects. Vet. J. 2009, 180, $149-162$. [CrossRef]

99. Cornell, K.K.; Bostwick, D.G.; Cooley, D.M.; Hall, G.; Harvey, H.J.; Hendrick, M.J.; Pauli, B.U.; Render, J.A.; Stoica, G.; Sweet, D.C.; et al. Clinical and pathologic aspects of spontaneous canine prostate carcinoma: A retrospective analysis of 76 cases. Prostate 2000, 45, 173-183. [CrossRef]

100. Leav, I.; Ling, G.V. Adenocarcinoma of the canine prostate gland. Cancer 1968, 22, 1329-1345. [CrossRef]

101. Reiter, E.; McNamara, M.; Closset, J.; Hennen, G. Expression and functionality of luteinizing hormone/chorionic gonadotropin receptor in the rat prostate. Endocrinology 1995, 136, 917-923. [CrossRef]

102. Tao, Y.-X.; Lei, Z.; Woodworth, S.; Rao, C. Novel expression of luteinizing hormone/chorionic gonadotropin receptor gene in rat prostates. Mol. Cell. Endocrinol. 1995, 111, R9-R12. [CrossRef]

103. Ponglowhapan, S.; Church, D.; Khalid, M. Expression of luteinizing hormone and follicle-stimulating hormone receptor in the dog prostate. Theriogenology 2012, 78, 777-783. [CrossRef]

104. Hardie, E.M.; Barsanti, J.A.; Rawlings, C.A. Complications of prostatic surgery. J. Am. Anim. Hosp. Assoc. 1984, 20, 50-56.

105. Basinger, R.R.; Rawlings, C.A.; Barsanti, J.A.; Oliver, J.E. Urodynamic alterations associated with clinical prostatic diseases and prostatic surgery in 23 dogs. J. Am. Anim. Hosp. Assoc. 1989, 25, 385-392.

106. Osborne, C.A.; Low, D.G.; Perman, V.; Barnes, D.M. Neoplasms of the canine and feline urinary bladder: Incidence, etiologic factors, occurrence and pathologic features. Am. J. Vet. Res. 1968, 29, 2041-2055.

107. Strafuss, A.C.; Dean, M.J. Neoplasms of the canine urinary bladder. J. Am. Vet. Med. Assoc. 1975, 166, 1161-1163.

108. Tarvin, G.; Patnaik, A.; Greene, R. Primary urethral tumors in dogs. J. Am. Vet. Med. Assoc. 1978, 172, 931-933.

109. Wilson, G.P.; Hayes, H.M.; Casey, H.W. Canine urethral cancer. J. Am. Anim. Hosp. Assoc. 1979, 15, 741-744.

110. Esplin, D.G. Urinary bladder fibromas in dogs: 51 cases (1981-1985). J. Am. Vet. Med. Assoc. 1987, 190, 440-444.

111. Norris, A.M.; Laing, E.J.; Valli, V.E.O.; Withrow, S.J.; Macy, D.W.; Ogilvie, G.K.; Tomlinson, J.; McCaw, D.; Pidgeon, G.; Jacobs, R.M. Canine Bladder and Urethral Tumors: A Retrospective Study of 115 Cases (1980-1985). J. Vet. Intern. Med. 1992, 6, 145-153. [CrossRef] 
112. Ponglowhapan, S.; Church, D.; Khalid, M. Differences in the expression of luteinizing hormone and follicle-stimulating hormone receptors in the lower urinary tract between intact and gonadectomised male and female dogs. Domest. Anim. Endocrinol. 2008, 34, 339-351. [CrossRef]

113. Schwalenberg, T.; Stolzenburg, J.U.; Ho, T.P.; Mallock, T.; Hartenstein, S.; Alexander, H.; Zimmermann, G.; Hohenfellner, R.; Denzinger, S.; Burger, M.; et al. Enhanced urothelial expression of human chorionic gonadogropin beta (hCG beta) in bladder pain syndrome/interstitial cystitis (BPS/IC). World J. Urol. 2012, 30, 411-417. [CrossRef]

114. Wycislo, K.; Fan, T.M. The Immunotherapy of Canine Osteosarcoma: A Historical and Systematic Review. J. Vet. Intern. Med. 2015, 29, 759-769. [CrossRef] [PubMed]

115. Cooley, D.M.; Beranek, B.C.; Schlittler, D.L.; Glickman, N.W.; Glickman, L.T.; Waters, D.J. Endogenous gonadal hormone exposure and bone sarcoma risk. Cancer Epidemiol. Biomark. Prev. 2002, 11, 1434-1440.

116. Ru, G.; Terracini, B.; Glickman, L. Host related risk factors for canine osteosarcoma. Vet. J. 1998, 156, 31-39. [CrossRef]

117. Yamamoto, S.; Hoshi, K.; Hirakawa, A.; Chimura, S.; Kobayashi, M.; Machida, N. Epidemiological, Clinical and Pathological Features of Primary Cardiac Hemangiosarcoma in Dogs: A Review of 51 Cases. J. Vet. Med. Sci. 2013, 75, 1433-1441. [CrossRef] [PubMed]

118. Lei, Z.M.; Rao, C.V.; Pridham, D. Novel coexpression of human chorionic gonadotropin/luteinizing hormone receptors and their ligand hCG in human fallopian tubes. J. Clin. Endocrinol. Metab. 1993, 132, 2262-2270.

119. Reshef, E.; Lei, Z.M.; Rao, C.; Pridham, D.D.; Chegini, N.; Luborsky, J.L. The Presence of Gonadotropin Receptors in Nonpregnant Human Uterus, Human Placenta, Fetal Membranes, and Decidua. J. Clin. Endocrinol. Metab. 1990, 70, 421-430. [CrossRef]

120. Ware, W.A.; Hopper, D.L. Cardiac tumors in dogs: 1982-1995. J. Vet. Intern. Med. 1999, 13, 95-103.

121. Zwida, K.H.; Valentine, B.A.; Kutzler, M.A. Immunohistochemical Localization of LH Receptors in Canine Splenic Hemangiosarcoma. J. Vet. Sci. Anim. Husb. 2018, 6, 410.

122. Shoop-Worrall, S.; Marlow, S.; Church, D.B.; English, K.; McGreevy, P.; Stell, A.; Thomson, P.C.; O’Neill, D.; Brodbelt, D.C. Prevalence and risk factors for mast cell tumours in dogs in England. Canine Genet. Epidemiol. 2015, 2, 1. [CrossRef]

123. Venencie, P.Y.; Méduri, G.; Pissard, S.; Jolivet, A.; Loosfelt, H.; Milgrom, E.; Misrahi, M. Luteinizing hormone/human chorionic gonadotrophin receptors in various epidermal structures. Br. J. Dermatol. 1999, 141, 438-446. [CrossRef]

124. White, C.R.; Hohenhaus, A.E.; Kelsey, J.; Procter-Gray, E. Cutaneous MCTs: Associations with Spay/Neuter Status, Breed, Body Size, and Phylogenetic Cluster. J. Am. Anim. Hosp. Assoc. 2011, 47, 210-216. [CrossRef] [PubMed]

125. Moccia, V.; Löhr, C.; Kutzler, M. Immunohistochemical localization of LH receptors in canine cutaneous mast cell tumor. In Proceedings of the Symposium for the Alliance for Contraception in Cats and Dogs, Boston, MA, USA, 22-24 July 2018.

126. Vail, D.M.; MacEwan, E.G.; Young, K.M. Canine lymphoma and lymphoid leukemia. Small Anim. Clin. Oncol. 2001, 558-579.

127. Su, S.; Fang, F.; Liu, Y.; Li, Y.; Ren, C.; Zhang, Y.; Zhang, X. The compensatory expression of reproductive hormone receptors in the thymus of the male rat following active immunization against GnRH. Gen. Comp. Endocrinol. 2013, 185, 57-66. [CrossRef] [PubMed]

128. Ettinger, A.M.; Gust, S.K.; A Kutzler, M. Luteinizing hormone receptor expression by nonneoplastic and neoplastic canine lymphocytes. Am. J. Vet. Res. 2019, 80, 572-577. [CrossRef] [PubMed]

129. Flint, C.; Gust, S.; Kutzler, M.A. Luteinizing hormone receptor-mediated proliferation of isolated canine T-lymphoma cells. Clin. Theriogenol. 2019, 11, 477.

130. Waters, D.J.; Kengeri, S.S.; Clever, B.; Booth, J.A.; Maras, A.H.; Schlittler, D.L.; Hayek, M.G. Exploring mechanisms of sex differences in longevity: Lifetime ovary exposure and exceptional longevity in dogs. Aging Cell 2009, 8, 752-755. [CrossRef]

(C) 2020 by the author. Licensee MDPI, Basel, Switzerland. This article is an open access article distributed under the terms and conditions of the Creative Commons Attribution (CC BY) license (http://creativecommons.org/licenses/by/4.0/). 